\title{
Percutaneous Reduction and Fixation of Intraarticular Calcaneal Fractures
}

Tim Schepers, Lucas M.M. Vogels, Inger B. Schipper, Peter Patka

\begin{abstract}
Objective Percutaneous reduction by distraction and subsequent percutaneous screw fixation to restore calcaneal and posterior talocalcaneal facet anatomy. The aim of this technique is to improve functional outcome and to diminish the rate of secondary posttraumatic arthrosis compared to conservative treatment and, secondly, to reduce infectious complications compared to open reduction and internal fixation (ORIF).
\end{abstract}

Indications Sanders type II-IV displaced intraarticular calcaneal fractures.

Contraindications Isolated centrally depressed fragment. Patients who are expected to be noncompliant.

Surgical Technique Four distractors (Synthes $\AA$ ) are positioned, two on each side of the foot, between the tuberosity of the calcaneus and talus and between the tuberosity and cuboid. A distracting force is given over all four distractors. A blunt drifter is then introduced from the plantar side to unlock and push up any remaining depressed parts of the subtalar joint surface of the calcaneus. The reduction is fixated with two or three screws inserted percutaneously.

\author{
Postoperative Management Directly \\ postoperatively, full active range of motion exercises of \\ the ankle joint can start, with the foot elevated in the 1st \\ postoperative week. Stitches are removed after 14 days. \\ Implant removal is necessary in $50-60 \%$ of patients.
}

Results Between 1999 and 2004, 59 patients with 71 fractures were treated by percutaneous skeletal triangular distraction and percutaneous fixation. A total of 50 patients with 61 fractures and a minimum follow-up of 1 year were available for follow-up. According to the American Orthopaedic Foot and Ankle Society Hindfoot Score, $72 \%$ had a good to excellent result. A secondary subtalar arthrodesis was performed in five patients and planned in four (total 15\%). Böhler's angle increased by about $20^{\circ}$ postoperatively. Sagittal motion was $90 \%$ and subtalar motion $70 \%$ compared to the healthy foot.

\section{Key Words \\ Calcaneal fracture Percutaneous \\ treatment - Protection of soft tissue}

Oper Orthop Traumatol 2008;20:168-75

DOI 10.1007/s00064-008-1239-5

Department of Surgery-Traumatology, Erasmus MC, University Medical Center Rotterdam, The Netherlands. 


\section{Perkutane Reposition und Fixation intraartikulärer Kalkaneusfrakturen}

\section{Zusammenfassung}

Operationsziel Perkutane Distraktion und anschließende perkutane Schraubenfixierung zur Wiederherstellung der Anatomie der Facetten des Fersenbeins und des hinteren Sprungbeins. Ziele dieser Technik sind eine Verbesserung des funktionalen Ergebnisses und eine Verminderung der Häufigkeitsrate der sekundären posttraumatischen Arthrose im Vergleich zur konservativen Behandlung sowie eine Senkung infektiöser Komplikationen im Vergleich zur offenen Reposition und inneren Fixation (ORIF).

Indikationen Dislozierte intraartikuläre Kalkaneusfrakturen Typ Sanders II-IV.

Kontraindikationen Isoliertes, zentrales Depressionsfragment. Patienten, bei denen mangelnde Mitarbeit zu erwarten ist.

Operationstechnik Es werden vier Distraktoren (Synthes $\circledast$ ) positioniert, zwei auf jeder Seite des Fußes, jeweils zwischen der Tuberositas des Fersenbeins und des Sprungbeins sowie zwischen der Tuberositas und dem Kuboid. Bei allen vier Distraktoren wird Zugkraft eingesetzt. Ein Einschlaginstrument wird dann plantar angesetzt, um die verbleibenden zertrümmerten Teile der subtalaren Gelenkoberfläche des Kalkaneus zu lösen und jegliche verbleibenden Teile heraufzuschieben. Die Reposition wird mit zwei oder drei perkutan eingebrachten Schrauben stabilisiert.

WeiterbehandlungUnmittelbar postoperativ kann mit Übungen des oberen Sprunggelenks begonnen werden, wobei der Fuß in der

1.Woche hochgelagert wird. Die Fäden werden nach 14 Tagen entfernt. Eine Schraubenentfernung ist bei $50-60 \%$ der Patienten erforderlich.

Ergebnisse Zwischen 1999 und 2004 wurden 59 Patienten mit 71 Frakturen mittels perkutaner dreiseitiger Distraktion und perkutaner Fixation behandelt. Insgesamt 50 Patienten mit 61 Frakturen und einer Mindestnachsorge von 1 Jahr standen bei der Nachuntersuchung zur Verfügung. Laut dem American Orthopaedic Foot and Ankle Society
Hindfoot Score wiesen $72 \%$ der Patienten ein gutes bis ausgezeichnetes Ergebnis auf. Eine sekundäre subtalare Arthrodese wurde bei fünf Patienten durchgeführt und war bei vier Patienten geplant (insgesamt 15\%). Der

Böhler-Winkel stieg postoperativ um rund $20^{\circ}$. Im Vergleich zum gesunden Fuß lagen der sagittale Bewegungsumfang bei $90 \%$ und der subtalare Bewegungsumfang bei $70 \%$.

\section{Schlüsselwörter}

\section{Kalkaneusfraktur · Perkutane Behandlung .} Weichteilschutz

Introductory Remarks One of the earliest descriptions of minimally invasive treatment of calcaneal fractures through ligamentotaxis was by Clark in 1855 [5], who described a pulley system to realign the arch of the foot.

Restoring calcaneal anatomy by distraction was further developed by Böhler in the late 1920s, and for some time percutaneous repair by traction with or without subsequent screw fixation was the most accepted treatment for intraarticular calcaneal fractures [16]. Later, open reduction through an extended lateral approach and rigid internal fixation with plate osteosynthesis (ORIF) became the standard operative treatment of displaced intraarticular calcaneal fractures. The most feared disadvantage of ORIF is the occurrence of wound complications with infection rates in the literature ranging from $0.4 \%$ to $27 \%[1,15,23]$. Higher percentages of soft-tissue complications are mentioned, but these do not differentiate between wound dehiscence, superficial and deep infections [15]. In the largest randomized controlled trial, 5\% deep and 17\% superficial wound infections were seen [4]. The soft tissues, damaged by the trauma, determine outcome [11] and infectious complications of treatment are costly [2]. Therefore, special care has to be given to the tissue envelope surrounding the calcaneus. For this reason minimally invasive procedures, with or without guidance of arthroscopy or perioperative (three-dimensional) CT scanning, are reemerging $[10,14,20,21]$. The three-point distraction technique as described by Forgon \& Zadravecz has been used, with minor modifications, at our institute since 1998 [8, 22]. 
Surgical Principles and Objective treatment, in order to reduce the secondary trauma Percutaneous treatment by skeletal distraction and and subsequent complication rates to the soft tissues screw fixation of displaced intraarticular fractures of as seen in the open reduction and fixation tech-the calcaneus, with functional postoperative after-niques.

\section{Advantages}

- Applicable to all types of displaced intraarticular calcaneal fractures, also to severely comminuted fractures.

- $\quad$ Additional damage of soft tissues is avoided; only small stab-wound incisions are necessary.

- $\quad$ Applicable in patients with compromised soft tissues and/or comorbidity like diabetes.

- Distraction pins are not left in place lowering the risk of infectious complications.

- $\quad$ Shorter learning curve in comparison to ORIF.

\section{Disadvantages}

- Indirect reduction of subtalar joint with the image intensifier may not result in an exact anatomic reduction.

- Percutaneous screw fixation is less rigid than plate osteosynthesis. Slight flattening of Böhler's angle may occur postoperatively.

- $\quad$ Patients are, like with ORIF, not allowed to bear weight for 12 weeks.

\section{Indications}

- All displaced intraarticular calcaneal fractures, Sanders type II-IV.

\section{Contraindications}

- Centrally depressed fractures are not manageable by traction alone.

- $\quad$ Patients who are expected to be noncompliant.

- $\quad$ Fractures older than 7 days, because of progressive stiffening of the soft tissues, the capsula and ligaments in particular.

\section{Patient Information}

- $\quad$ On average $<10 \%$ wound complications, with usually a mild presentation.

- $\quad$ Small percentage (10-15\%) of neurapraxia, lateral dorsal cutaneous nerve (continuation of the sural nerve), with temporary numbness on the lateral side of the foot.

- $\quad$ Non-weight bearing for 12 weeks.

- Intensive physiotherapy.

- $\quad$ Recovery time after surgery may be up to 1 year.

- $\quad$ Chance of osteoarthritis with persistent pain at rest and during walking, with indication for secondary arthrodesis in $10-15 \%$.

\section{Preoperative Work Up}

- Clinical evaluation of soft tissues, function, vascular status, and sensibility.

- $\quad$ Conventional radiographs (lateral and axial), CT

scan with reconstructions in the sagittal, axial and (semi)coronal plane.

- $\quad$ Routine preoperative laboratory tests.

- $\quad$ Rest, cryotherapy, compressive dressings, and elevation are administered in case of significant edema. Foot pumps can be used to reduce swelling more rapidly.

- $\quad$ Perioperative single-dose antibiotic prophylaxis

(e.g., cephalosporin), following local hospital protocol.

\section{Surgical Instruments and Implants}

- Two orthogonally placed fluoroscopes (axial and sagittal).

- $\quad$ Three 3-mm Kirschner wires, 15-20 cm in length.

- Four distractors (custom-made by Synthes).

- $\quad$ Two or three threaded guide wires and 6.5-mm cannulated cancellous bone screws.

\section{Anesthesia and Positioning (Figure 1)}

- Spinal or general anesthesia.

- $\quad$ Prone position with affected foot slightly elevated for sagittal fluoroscopy.

- $\quad$ Two sterile-draped C-arms positioned at the end of the table, with the monitor beside the operating table, next to anesthesiologist's equipment. No tourniquet is needed. 


\section{Figure 1}

Patient in prone position, with the affected foot elevated. Two fluoroscopes in sagittal and axial direction placed before sterile draping of the C-arms.

\section{Surgical Technique}

\section{Figures 2 to 6}

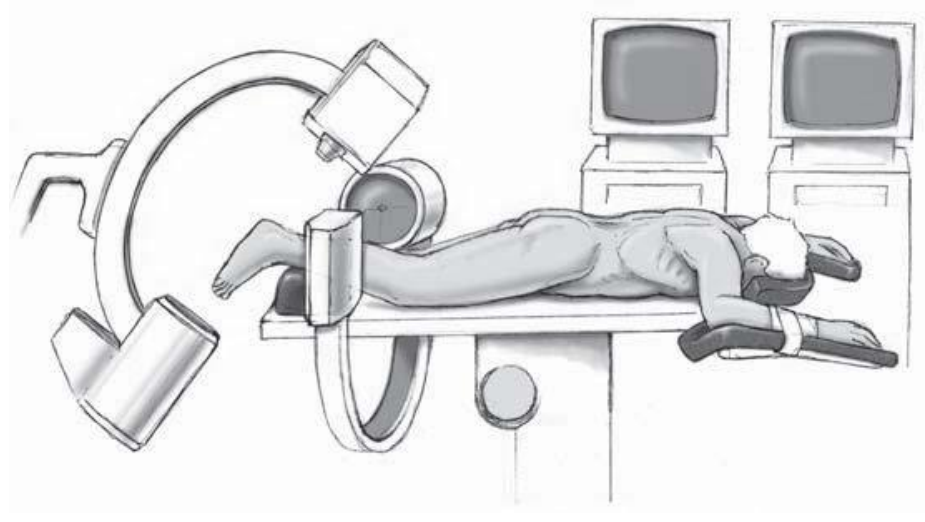

\section{Figure 2}

Three 3-mm Kirschner wires are inserted from the lateral side through the calcaneal tuberosity, the cuboid and the talar neck. The direction of the Kirschner wires has to be chosen on the basis of the tuberosity's displacement. If, for example, the heel is in varus position, the Kirschner wires are inserted converging from lateral to medial to correct varus of the heel pulling the tuberosity in a neutral position when distraction is applied.

\section{Figure 3}

Two distractors are mounted on each side of the foot and winded apart to restore calcaneal height and length - in this case between the tuberosity of the calcaneus and talus and between the tuberosity and cuboid to obtain both height and length, comparable to the orientation used by McBride [18]
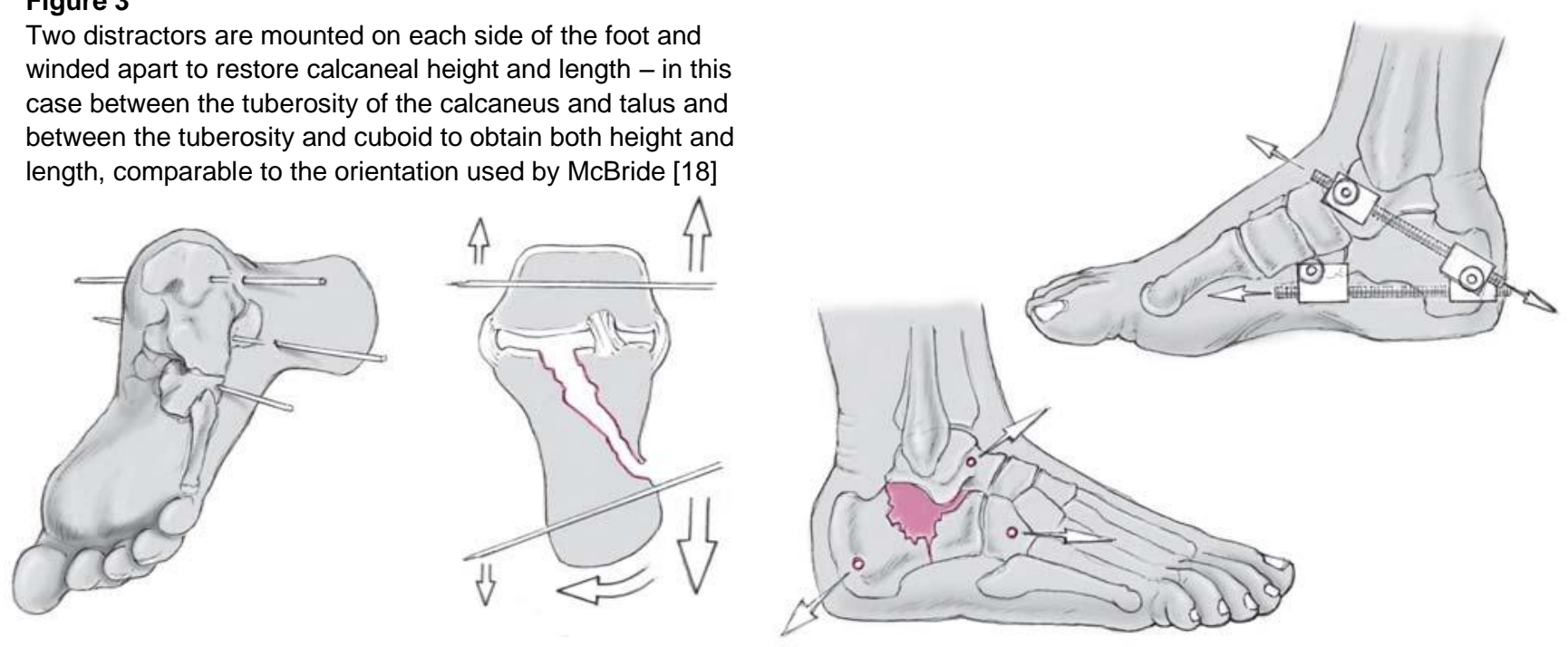

and Kuner et al. [13]. 


\section{Figure 4}

Insertion of a blunt drifter (punch) to unlock the de-

pressed part of the posterior talocalcaneal facet in order to restore joint congruence.
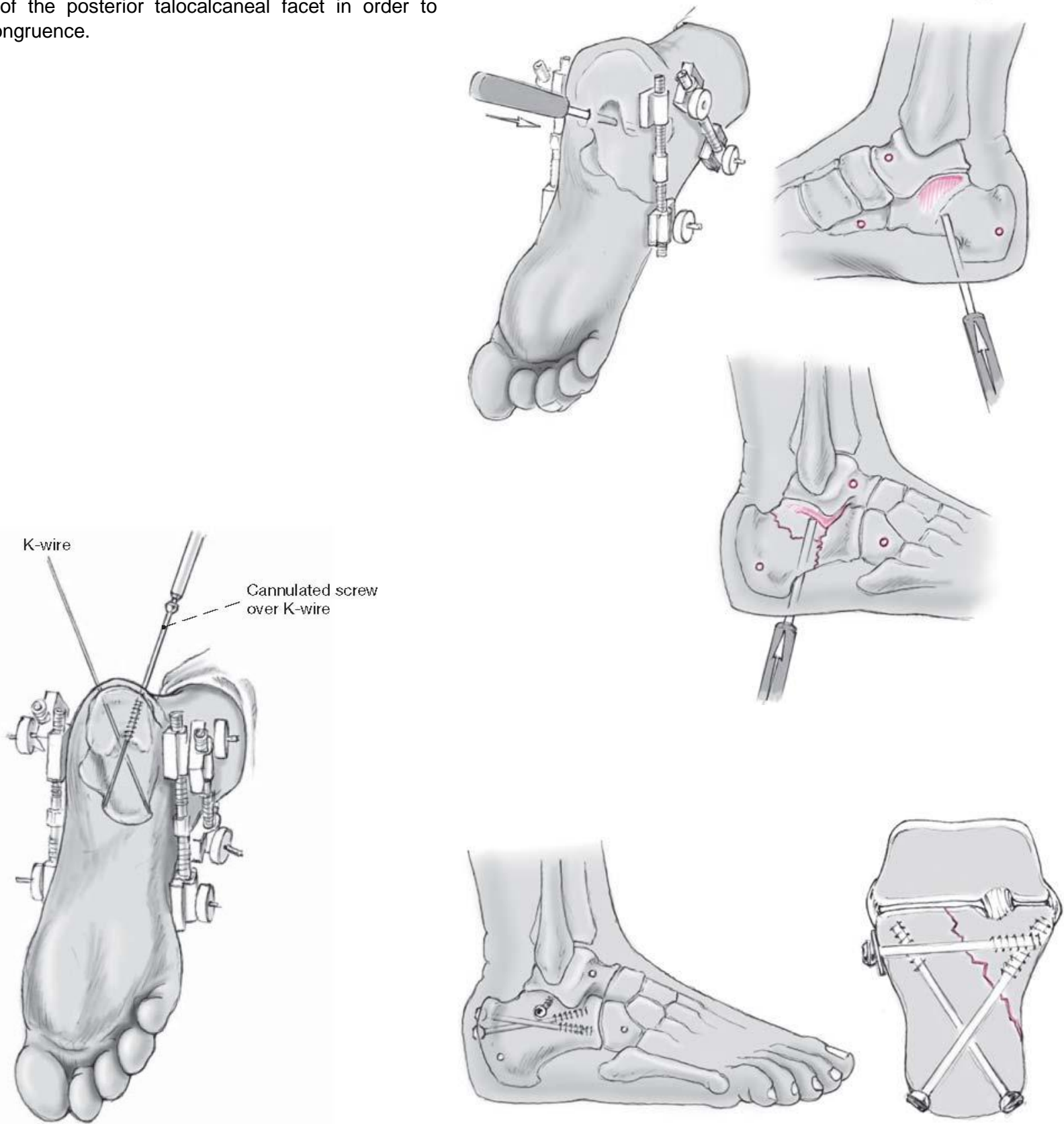

Blunt drifter

\section{Figure 5}

When acceptable reduction is obtained, two crossing 3-mm Kirschner wires are inserted from the calcaneal tuberosity toward the cuboid and navicular bone. These are then replaced by cannulated cancellous screws crossing each other. Care is given that they are not drilled into the adjacent bones. A third cannulated screw is inserted from the lateral side and guided into the sustentaculum, to reduce width. This transversely placed screw maintains the correction of width, obtained by the percutaneous distraction. If used in combination with a 
washer, this screw provides additional reduction of the latera wall and any fracture lines in the subtalar joint.

Figure 6
Final result in lateral and axial view after dismounting the external distractors. 


\section{Special Considerations}

In fractures with severe height loss, the distractors can be mounted from talus to calcaneus and talus to cuboid on both sides of the foot according to Forgon and Forgon \& Zadravecz [7, 8].

- Instead of a blunt drifter from plantar, a Kirschner wire inserted into the lateral fragment can be used as lever to lift up the fragment.

- $\quad$ Two-point distraction, e.g., by Sanatmetal (Hungary) and I.T.S. (Austria), between talus and calcaneal tuberosity is an option, especially in less comminuted fractures [9].

- If, during the operation, a small unstable fragment of the posterior talocalcaneal joint cannot be bridged or supported by the cannulated screws and recollapses, it can be temporarily fixated by a transarticular Kirschner wire [3, 24]. This, however, delays functional aftertreatment [19]. ture line(s)

Direction of screw placement depends on the frac-

- Intraoperative use of CT scanning or subtalar arthroscopy might be considered to verify anatomic reduction of the subtalar joint $[10,17,20,21]$.

\section{Postoperative Management}

- Directly postoperatively, full active range of motion exercises of the ankle joint can start, with the foot elevated in the 1st postoperative week.

- $\quad$ Adequate analgesics are mandatory.

- $\quad$ The physiotherapist can assist in the exercises, and the teaching of walking with crutches.

- Conventional radiographic control images are obtained postoperatively. The next radiographic check will be at 6 weeks and at 3 months.

- $\quad$ Stitches are removed after 14 days.

- Implant removal is necessary in $50-60 \%$ of patients. Complaints in terms of shoe wearing are mostly caused by distal migration of the two screw heads, which is due to a slight collapse of the posterior facet at follow-up. Removal of the cannulated screws can be considered after approximately 6 months. If a

\section{Figure 7}

Case 1: a 32-year-old female patient was transferred to our hospital with an Essex-Lopresti tongue-type and Sanders type IIB fracture of her right calcaneus after jumping from a second-story window. After 4 days a percutaneous reduction by distraction with screw fixation was performed. An additional transarticular Kirschner wire was inserted to prevent the reduced subtalar joint from secondary collapse. The follow-up period is now 1 month, the transarticular Kirschner wire will be removed after 6-8 weeks.
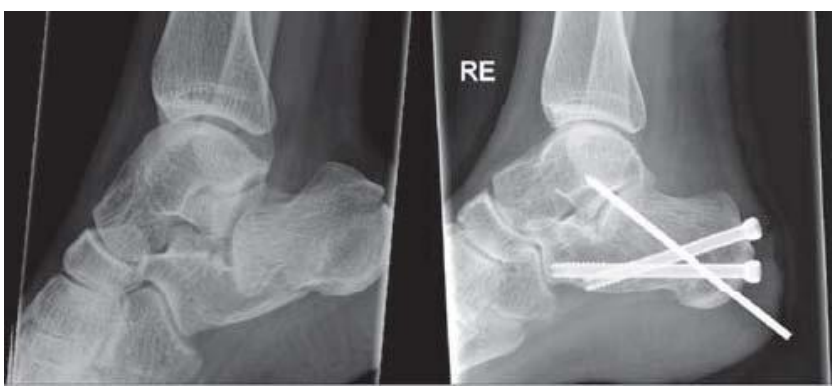

Figure 8

Case 2: a 24-year-old male patient fell from $2 \mathrm{~m}$ landing on his right foot. He sus-tained an Essex-Lopresti joint-depression and Sanders IIIAC type fracture, with luxa-tion of the subtalar joint. The luxation and fracture were operated on the same day. After a follow-up of 19 months the patient has minor complaints of stiffness, but no complaints of pain.
Figure 9

Case 3: a 43-year-old male patients fell from $3 \mathrm{~m}$ sustaining a bilateral calcaneal frac-ture. On the left, the fracture was classified as an Essex-Lopresti tongue-type and a Sanders type IIC. The operation appeared radiologically successful at 3 and 12 months, but the patient remained painful and a secondary subtalar arthrodesis was per-formed after 14 months. 


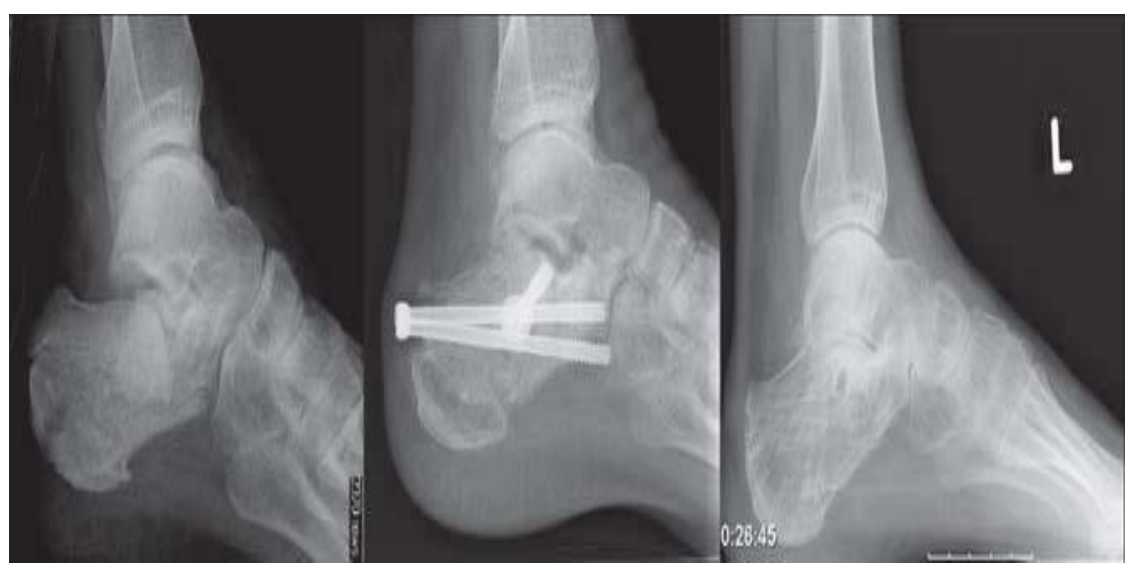


transarticular Kirschner wire was used, it is removed after 6-8 weeks.

- After 12 weeks, and following assessment of healing on control radiographs, patients are allowed to start weight bearing.

\section{Errors, Hazards, Complications}

- Secondary collapse of fragments: direction of the screws has to be chosen correctly to bridge large fragments and to support posterior facet fragments. As the extent of secondary collapse is usually minor, this needs no further treatment. In case of severe collapse, causing subtalar joint incongruency, an open revision should be considered.

- Injury to the lateral dorsal cutaneous nerve, the continuation of the sural nerve: this complication occurs in approximately $10 \%$, and gives a temporary numbness on the lateral side of the foot, which requires no treatment.

- Peroneal tendon impingement or fibular abutment: if initial correction of the calcaneal width was insufficient, a secondary excision of the lateral wall exostosis can be performed.

- Intraarticular screw placement: this requires removal of the hardware prior to weight bearing mobilization.

- $\quad$ Surgical site infection: may be treated with antibiotics with or without wound debridement.

Results Between 1999 and 2004, 59 patients with 71 fractures were treated at our institute by percutaneous skeletal triangular distraction [22] (for examples see Figures 7 to 9 ). A total of 50 patients with 61 fractures and a minimum follow-up of 1 year were available at a mean follow-up of $35 \pm 20$ months. $72 \%$ were male, mean age was $46 \pm 12$ years.

According to the Essex-Lopresti classification, 38\% of the injuries were joint-depression fractures, $15 \%$ tongue-type, $44 \%$ comminuted, and $3 \%$ unknown fractures. The Sanders classification showed type II in 38\%, type III in $28 \%$, type IV in $28 \%$, and an unknown type in $6 \%$. There were five open fractures.

According to the American Orthopaedic Foot and Ankle Society Hindfoot Score [6, 12], 72\% of all patients had a good (80-89 points) or excellent (90-100 points) result; the mean score was $83 \pm 14$ points. Nine patients developed wound complications: seven superficial infections, one osteomyelitis, and one pin tract infection. Five patients already underwent, and four patients were scheduled for, secondary arthrodesis (total nine out of 61 feet). Böhler's angle increased from $-2^{\circ}\left( \pm 16^{\circ}\right)$ to $19^{\circ}\left( \pm 10^{\circ}\right)$ postoperatively. In 32 patients, the healthy side measured $31^{\circ}\left( \pm 5^{\circ}\right)$ on average. At follow-up, the average Böhler's angle was $14^{\circ}\left( \pm 12^{\circ}\right)$, a collapse of $5^{\circ}$. Sagittal motion was $90 \%$ and subtalar motion $70 \%$ compared to the healthy foot. Previous studies with this treatment modality show comparable results.

Forgon showed, in a large population of 265 patients with a calcaneal fracture, a good to excellent result in $90 \%$. The complications included wound healing disturbances in $3.7 \%$ and loss of reduction in $6.1 \%$. No comments were made on the need for a secondary arthrodesis [7].

Fröhlich et al. treated 94 patients percutaneously with a modified Forgon-Zadravecz technique using a two-point distractor by Sanatmetal and reported a good to excellent result in $80 \%$, with wound healing complications in $2.1 \%$ and the need for a secondary arthrodesis in another $2.1 \%$ [9].

In conclusion, percutaneous reduction by skeletal distraction and screw fixation can be considered a useful treatment modality, especially in severely comminuted fractures, expected wound complications in open fractures and patients with diabetes or peripheral vascular occlusive disease.

The outcome from larger series, showing improved anatomic reduction with the use of intraoperative scanning or arthroscopy, might answer the question, if minimally invasive calcaneal repair is as effective as ORIF.

\section{Acknowledgment}

We thank the Japanese Orthopaedic Association for granting us permission to reprint data previously published in the Journal of Orthopaedic Science 2007, volume 12, pages 22-27, by T. Schepers et al., entitled "Percutaneous treatment of displaced intra-articular calcaneal fractures".

\section{References}

1 Bèzes $H$, Massart $P$, Delvaux $D$, et al. The operative treatment of intraarticular calcaneal fractures. Indications, technique, and results in 257 cases. Clin Orthop 1993;290:55-9.

2 Brauer CA, Manns BJ, Ko M, et al. An economic evaluation of operative compared with nonoperative management of displaced intra-articular calcaneal fractures. J Bone Joint Surg Am 2005;87:2741-9.

3 Buch J, Blauensteiner W, Scherafati T, et al. Konservative Behandlung des Fersenbeinbruches versus Reposition und perkutane Bohrdrahtfixation. Vergleich zweier Methoden. Unfallchirurg 1989;92:595-603.

$4 \quad$ Buckley R, Tough S, McCormack R, et al. Operative compared with non-operative treatment of displaced intra-articular calcaneal fractures: a prospective, randomized, controlled multicenter trial. J Bone Joint Surg Am 2002;84:1733-44.

$5 \quad$ Clark LG. Fracture of the os calcis. Lancet $1855 ; 65: 403-4$. 
6. Follak $\mathrm{N}$, Merk $\mathrm{H}$. The benefit of gait analysis in functional diagnostics in the rehabilitation in patients after operative treatment of calcaneal fractures. Foot Ankle Surg 2003;9:209-14.

7. Forgon M. Closed reduction and percutaneous osteosynthesis: technique and results in 265 calcaneal fractures. In: Tscherne H, Schatzker $\mathrm{J}$, eds. Major fractures of the pilon, the talus, and the calcaneus. New York: Springer, 1993:207-13.

8. Forgon M, Zadravecz G. Die Kalkaneusfraktur. Berlin: Springer, 1990:1-104.

9. Fröhlich P, Zakupszky Z, Csomor L. Erfahrungen mit der gedeckten Verschraubung intraartikularer Fersenbeinbrüche. Operationstechnik und klinische Ergebnisse. Unfallchirurg 1999;102:359-64.

10. Gavlik JM, Rammelt S, Zwipp H. Percutaneous,

arthroscopically-assisted osteosynthesis of calcaneus fractures. Arch

Orthop Trauma Surg 2002; 122:424-8.

11. Heier KA, Infante AF, Walling AK, et al. Open fractures of the calcaneus: soft-tissue injury determines outcome. J Bone Joint Surg Am 2003;85: 2276-82.

12. Kitaoka HB, Alexander IJ, Adelaar RS, et al. Clinical rating systems for the ankle-hindfoot, midfoot, hallux, and lesser toes. Foot Ankle Int $1994 ; 15: 349-53$

13. Kuner EH, Bonnaire F, Hierholzer B. Zur Klassifikation und Osteosynthesetechnik der Kalkaneusfrakturen. Der Fixateur externe als passagerer Distraktor. Unfallchirurg 1995;98:320-7.

14. Levine DS, Helfet DL. An introduction to the minimally invasive osteosynthesis of intra-articular calcaneal fractures. Injury 2001;32:Suppl 1:

SA51-4.

15. Lim EVA, Leung JPE. Complications of intraarticular calcaneal fractures. Clin Orthop 2001;391:7-16.

16. MacAusland W. The treatment of comminuted fractures of the os calcis. Surg Gynecol Obstet 1941;73:671-5.

17. Mayr E, Hauser H, Ruter A, et al. Minimal-invasive, intraoperativ CT-gesteuerte Korrektur einer Kalkaneusosteosynthese. Unfallchirurg 1999; 102:239-44.

1. McBride ED. Fractures of the os calcis; tripod-pin-traction apparatus. J Bone Joint Surg 1944;26:578-9.

2. Rammelt S, Amlang M, Barthel S, et al. Minimally invasive treatment of calcaneal fractures. Injury 2004;35:Suppl 2:SB55-63.

3. Richter M, Geerling J, Zech S, et al. Intraoperative three-dimensional imaging with a motorized mobile C-arm (SIREMOBIL ISO-C-3D) in foot and ankle trauma care: a preliminary report. J Orthop Trauma 2005;19:259-66.

4. Rübberdt A, Feil R, Stengel D, et al. Die klinische Wertigkeit des ISO-C(3D) bei der Osteosynthese des Fersenbeins. Unfallchirurg 2006;109:112-8.

5. Schepers T, Schipper IB, Vogels LM, et al. Percutaneous treatment of displaced intra-articular calcaneal fractures. J Orthop Sci 2007;12:22-7.

6. Stephenson JR. Treatment of displaced intra-articular fractures of the calcaneus using medial and lateral approaches, internal fixation, and early motion. J Bone Joint Surg Am 1987;69:115-30.

7. Stulik J, Stehlik J, Rysavy M, et al. Minimally invasive treatment of intra-articular fractures of the calcaneum. J Bone Joint Surg $\mathrm{Br}$ 2006; 88:1634-41.

\section{Address for Correspondence}

Tim Schepers, MD Department of Surgery-Traumatology Erasmus MC University Medical Center Rotterdam Room H974 PO Box 20403000 CA Rotterdam The Netherlands Phone (+31/10) 703-1050, Fax -2396 e-mail:

t.schepers@erasmusmc.nl

\section{䖧椀最甀爀攀.}

